\title{
有機系太陽電池の光電変換効率の理論限界
}

\author{
関和 彦 \\ 産業技術総合研究所 凿 305-8565 茨城県つくば市東 1-1-1 産総研第 5 \\ (2014 年 7 月 15 日受付；2014 年 8 月 28 日掲載決定)
}

\section{Theoretical Limits of Power Conversion Efficiency for Organic Photovoltaic Cells}

\author{
Kazuhiko SEKI
}

National Institute of Advanced Industrial Science and Technology, AIST Central 5, 1-1-1 Higashi, Tsukuba, Ibaraki 305-8565

(Received July 15, 2014 ; Accepted August 28, 2014)

\begin{abstract}
Organic and inorganic photovoltaic cells can be classified as excitonic solar cells and pn-junction solar cells, respectively. In this article, a fundamental difference in the operational mechanism between them is explained. The detailed balance limit of power conversion efficiency (PCE) was already established for pn-junction solar cells by Shockley and Queisser. Recent attempts to obtain theoretical limits of PCE for excitonic solar cells are reviewed.
\end{abstract}

KEYWORDS : organic solar cells, excitonic solar cells, power conversion efficiency

\section{1.は じめに}

有機系の太陽電池は, 有機物質に特有の軽く, 曲げや すく，資源が豊富であるという長所を持つ。従来の太陽 電池では困難であった, 曲面への適用や, 軽さを活かし た用途等, 広範な利用の可能性を持つ次世代の太陽電池 として注目されている。近年, エネルギー変換効率も著 しく向上し, 2011 年以降, 三菱化学や住友化学等が, 単一素子およびタンデム素子により $10 \%$ を超える効率 を上げている ${ }^{1)}$ 。発電の安定性や有機材料の寿命等, 克 服すべき課題もあるが, 変換効率はアモルファスシリコ ン太陽電池に匹敵している。本解説では，有機薄膜太陽 電池の変換効率はどこまで向上できるのかという原理的 な問題に焦点を絞ることにする。従来の無機系太陽電池 に対して導かれた理論限界を有機系太陽電池にそのまま 適用するのには, 有機系と無機系太陽電池の光電変換の 機構の違いが考慮されていないという問題点がある。有 機系太陽電池の光電変換の機構について解説し, 有機系 太陽電池に対する光電変換の理論限界を求める最近の試 みについて紹介する。

太陽光のエネルギー変換効率 (光電変換効率) は, 電

E-mail : k-seki@aist.go.jp
流密度（単位時間, 単位面積を流れる電荷量）と電圧の 積である単位面積当たりの電力を, 単位時間, 単位面積 当たり入射する太陽光のエネルギーで割った值で特徴付 けられる。光電変換効率と同様に, 太陽電池の効率を表 すのに良く使われている指標に, 内部量子収率（Internal quantum efficiency, IQE) および外部量子収率（External quantum efficiency, EQE) がある。どちらの量子収率 も分子は電流密度で同じであるが分母が異なっている。 IQE では，単位時間に素子に吸収された単位面積当たり の光の量（光子の流れの密度）であるのに対して, $\mathrm{EQE}$ では単位時間, 単位面積に素子に照射された（透過光, 散乱光も含めた）光の量である。これらの量が高くて も, 電圧の損失があると, 電流と電圧の積である電力は 低くなってしまう。エネルギーの変換効率を上げるため には, 量子収率を上げる一方, 電圧の損失を抑える必要 がある。

現在主流の太陽電池は無機系の半導体が用いられてお り, GaAs の薄膜結晶の光電変換効率は, 米国国立再生 可能エネルギー研究所による各種太陽電池素子のチャー トによると $28.8 \%$ であり後述する理論值である約 $33 \%$ に，非常に近づいている ${ }^{1 \sim 3)}$ 。

本題の有機系太陽電池の変換効率について述べる前 に, 次章では入射する太陽光の性質についてまとめるこ 
とにする。

\section{2. 太陽光のエネルギー密度}

光電変換効率は, 地上での太陽光のエネルギー密度を 基準にして, 電力へ変換される割合により与えられる。 そこで, まず基準となる地上での太陽光スペクトルにつ いて解説する。太陽の表面温度は, 黒体輻射で近似する と約 $5800 \mathrm{~K}$ である。地球に降り注ぐ太陽光スペクトル は, Air mass（AM）を用いて表示されることが多い。 大気圈外でのスペクトルが AM0 であり, AM の後の数 值は太陽光が透過する空気の量 (Air mass) を表し, 地 上に垂直に太陽光が入射した場合に AM1 と表示され る。中緯度にある日本での太陽光の平均的なスペクトル としてAM1.5 が良く用いられる ${ }^{4)}$ 。Fig. 1 に, AM1.5の スペクトルを示す4)。横軸は $\mathrm{eV}$ で示しているために,

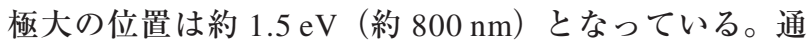
常のように波長で表示すると, 極大は約 $500 \mathrm{~nm}$ とな る。黒体輻射の波長表示での極大は, 黒体の温度 $\mathrm{T}[\mathrm{K}]$ と極大波長 $\lambda[\mu \mathrm{m}]$ の積との関係, $\mathrm{T}[\mathrm{K}] \lambda[\mu \mathrm{m}]$ $=3000[\mathrm{~K} \mu \mathrm{m}]$ より求めることができる。単位周波数 （または単位エネルギー）当たりと単位波長当たりで, スペクトルの極大がずれることは, 光速 $\mathrm{c}$ を用いて, 周

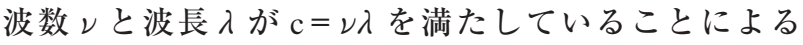
$\nu \mathrm{d} \lambda+\lambda \mathrm{d} \nu=0$ の関係による。スペクトルの波長での極大 が可視光，エネルギーまたは周波数での極大が近赤外光 となる。蛇足であるが，目は波長の極大がよく見えるよ うに機能しているといえるが，周波数で見ると必ずしも そうとはいえない。光電変換については, 太陽光スペク トルを積分した結果が用いられるので，横軸をエネルギ 一に取っても波長に取っても変換効率の極大が変わって しまうことはない。

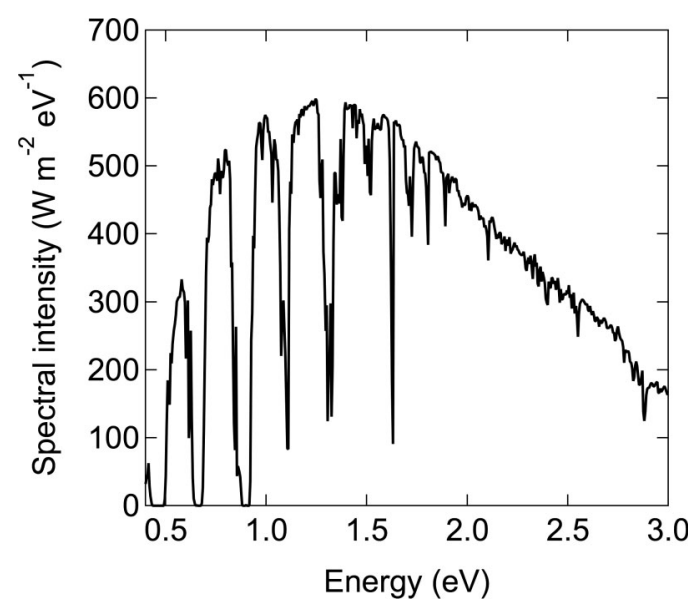

Fig. 1. AM1.5 spectrum as a function of photon energy.
なお, 地上に降り注ぐ太陽光の全エネルギーは $\mathrm{AM} 1.5$ のスペクトル $B_{\mathrm{E}}(E)$ の積分

$$
I(0)=\int_{0}^{\infty} d E^{\prime} B_{\mathrm{E}}\left(E^{\prime}\right)
$$

から約 $1 \mathrm{~kW} / \mathrm{m}^{2}$ となる。理論限界の分母を与える，入 射する太陽光の単位面積あたりの全エネルギーはこの值 である。

\section{3. 有機薄膜太陽電池の光電変換の機構}

多くの色素, 共役高分子の可視光の吸光係数は $10^{5}$ $\left[\mathrm{cm}^{-1}\right]$ を超えており $\mathrm{Si}$ 系の無機太陽電池と比較して高 く, $100 \mathrm{~nm}$ 程度の薄膜で十分な光吸収が得られる ${ }^{5)} 。$ 方, キャリア易動度は一般に無機系の半導体に比較して 桁違いに低いことから, 有機系太陽電池には薄膜が用い られている。無機系半導体の比誘電率が 10 程度である のに対して, 有機系材料は比誘電率が $3 \sim 4$ 程度と低く, クーロン相互作用が長距離に及ぶ。クーロン相互作用で 束縛されている正負の電荷が常温で解離できる距離は, 温度 $T$, ボルツマン定数 $k_{\mathrm{B}}$ を用いて $e^{2} /\left(4 \pi \varepsilon \varepsilon_{0} k_{\mathrm{B}} T\right)$ と表 され，Bjerrum 長と呼ばれる（Onsager 長やクーロン半 径とも呼ばれる)。電荷に対して $1.602 \times 10^{-19}$ [C] およ び真空の誘電率 $\varepsilon_{0}=8.85 \times 10^{-12}\left[\mathrm{C}^{2} /\left(\mathrm{Nm}^{2}\right)\right]$ を用い，有 機固体に典型的な比誘電率 $\varepsilon=3.5$ を用いると常温で 164 $\AA$ 程度となる。電荷対間の距離が $r_{0}=1 \mathrm{~nm}$ の場合, ク 一ロン相互作用の大きさを $e^{2} /\left(4 \pi \varepsilon \varepsilon_{0} r_{0}\right)$ から見積もる と, 比誘電率に $\varepsilon=3.5$ を用いると $0.3 \sim 0.4 \mathrm{eV}$ となり熱 エネルギー $0.026 \mathrm{eV}$ と比較して桁違いに大きい。この ため, 光で生成した励起子の電荷分離効率は低く, 初期 の有機系太陽電池の光電変換効率が低い要因となってい た。

この状況のブレークスルーは, 有機 EL の研究の蓄積 があった Tangによりなされた ${ }^{6)}$ 。Tang は電子供与性の 色素（ドナー）と, 電子吸引性の有機物質（アクセプ夕 一）の積層構造を作り, 電極と有機物質の界面よりもこ れら有機物質の組み合わせが，光電変換効率を決める主 要な因子であることを見いだし当時としては最高の 1.6 パーセントの変換効率を得た。この研究が契機となり, 一種類の有機物質では起こすことが難しかった電荷対の 分離を，ドナーとアクセプター間の界面を利用して効率 良く起こすことができることがわかり，変換効率が飛躍 的に向上した。

Fig. 2 に, 有機薄膜太陽電池での電荷分離する過程を 示す。ドナーの光吸収で生成した励起子は界面まで移動 し，ドナーとアクセプターの界面エネルギーの差により クーロン相互作用に抗して電荷分離する。電荷分離の 際，解離エネルギー $\Delta E_{\mathrm{DA}}$ の電位差を失い，電荷分離に 


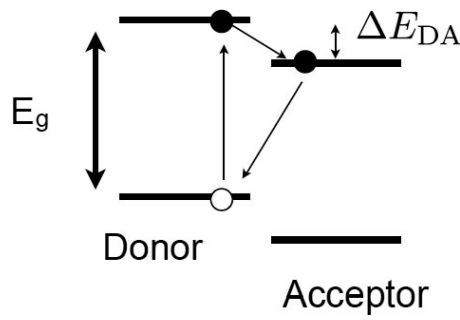

Fig. 2. Schematic energy diagram of charge dissociation processes in organic photovoltaic cells. The optical band-gap is denotes by $E_{\mathrm{g}}$ and the dissociation energy is denoted by $\Delta E_{\mathrm{DA}}$. The figure is reproduced from Ref. 7) with permission.

より生成したドナーカチオンとアクセプターアニオンの 間の電荷再結合が, キャリアすなわち電流の損失とな る7)。解離エネルギーの值については, ドナーの励起状 態を正確に求めなければならず, 計算化学においても挑 戦的な課題でありドナーやアクセプターに依存する。し かし, 電荷分離を高効率で起こさせるために必要な余剩 エネルギーの最低值については, 最低でも $0.3 \sim 0.4$ $[\mathrm{eV}]$ であると考えられている ${ }^{2,8)}$ 。後の章で, 開放端電 圧を計算し, 光学ギャップや余剩エネルギーとの理論的 な関係を示す。

一般に有機物質のキャリア易動度は小さいため, 薄膜 化した方が電力の損失を抑える上で望ましい。他方，ド ナー相とアクセプター相の界面の面積が多いほど界面で の電荷分離に対して有利である。キャリア輸送の観点で は，ドナー相とアクセプター相にはそれぞれ電極まで到 達するパスが確保されていなければならない。また, 励 起子には寿命 $\tau_{e}$ がある。励起子拡散係数を $D_{e}$ とすると 励起子拡散長 $\sqrt{D_{e} \tau_{e}}$ を定義でき, 界面から励起子拡散長 以内に生成した励起子でないと界面に到達せず失活して しまう。これらの要素を考慮して, 最近ではドナー相と アクセプター相が数 $10 \mathrm{~nm}$ 程度で入れ込んだ構造を取 るバルクヘテロ結合と呼ばれる構造の薄膜で高い光電変 換効率が得られている2,8)。

\section{4. 光電変換効率の理論限界}

太陽電池は電荷分離の機構により, 無機系の pn 接合 型と, 有機系の Excitonic 太陽電池に大別される ${ }^{7,8)}$ 。光 励起により物質内部で電荷分離する場合は, $\mathrm{p}$ 型半導体 と $\mathrm{n}$ 型半導体の接合による内部電場により, 正負それぞ れのキャリア電流を効率良く生じさせることができる。 この場合を pn 接合型と呼ぶ ${ }^{8,9)}$ 。これに対して, 光励起 により正負のキャリアが強く束縛された Exciton が生成 される場合を Excitonic 太陽電池と呼ぶ。Excitonic 太陽 電池では, 異種物質間の界面で電荷分離する。4.1 節に
おいて pn 接合型太陽電池の機構を取り上げ, それ以後 の節で Excitonic 太陽電池の機構を取り上げる。

\section{1 無機太陽電池}

1960 年代初頭に Shockley と Queisser は, 同種の無機 半導体のホモ接合について, 理論限界効率を求めた ${ }^{3)}$ 。 ホモ接合は $\mathrm{p}$ 型と $\mathrm{n}$ 型の半導体として同じ物質を使う。 Shockley と Queisser の理論 (SQ 理論) では, pn 接合 は，正負キャリアを速やかに分離させるキャリア輸送の ために暗に仮定されているが，無機半導体では電荷分離 はいたるところで起こっており, pn 接合による電圧低 下はないものとする。得られた理論限界の值は, 当初 は, 現実的な限界というょりむしろ原理的な限界である とされていたが, 現実の限界効率がこの理論限界に近づ いていることから興味が持たれるようになってきた。

SQ 理論では, 光解離したキャリアの電荷再結合によ る損失が考慮されている ${ }^{3)}$ 。電荷再結合には, 輻射再結 合と無輻射再結合がある。分子振動を介して起こる無輻 射再結合は抑制することができる。これに対して，定常 状態では，吸収した光は必ず輻射を伴う。SQ 理論では 光生成キャリアの輻射再結合は避けることができないキ ヤリアの損失を与えるとしている。さらに SQ 理論で は, 輻射再結合速度を素子の温度 (室温 $T_{\text {素子 }}$ ) の空洞中 に置かれた半導体からの輻射より求めた。輻射再結合に よる光子の流れは, 単位時間, 単位面積, 単位エネルギ 一あたり ${ }^{3)}$

$$
J_{\mathrm{E}}(E, T)=\frac{2 \pi E^{2}}{c^{2} h^{3}} \frac{1}{\exp \left[E /\left(k_{\mathrm{B}} T\right)\right]-1}
$$

である。以下では, 素子は室温であることから, ウィー ンの式に対応する $\left(\exp \left[E /\left(k_{\mathrm{B}} T\right)\right]-1\right)^{-1} \approx \exp [-E /$ $\left.\left(k_{\mathrm{B}} T\right)\right]$ という近似を行う。

素子を流れる電流がゼロであると, 電荷生成と電荷再 結合が対で起こるので物質中での正と負のキャリアの数 が等しい。このときのキャリア濃度を $n_{\mathrm{i}}$ と書く。バン ドギャップ以上のエネルギーで励起された正負キャリア 一対による電荷再結合速度は, 空洞中での輻射再結合の 速度から求めることができる。輻射再結合の速度は, 単 位時間，単位面積あたり

$$
J_{\mathrm{R}}\left(E_{\mathrm{g}}\right)=\int_{E_{\mathrm{g}}}^{\infty} d E J_{\mathrm{E}}(E, T \text { 素子 })
$$

であり正負のキャリア濃度の積 $n_{\mathrm{i}}{ }^{2}$ に比例する。

光照射により電流が流れ, 電極間に電位差 $V$ が生じ ている場合の電流と電圧の関係については, 負のキャリ ア濃度 $n_{e}$ と正のキャリア濃度 $n_{p}$ は平衡状態と同じょう に質量作用の法則が成り立つと仮定して求める。質量作 用の法則によると $n_{e} n_{p}=\exp \left[V /\left(k_{\mathrm{B}} T_{\text {素子 }}\right)\right] n_{\mathrm{i}}{ }^{2}$ という関係 を満たす。この関係を用いると再結合によるキャリアの 
流れは，単位時間，単位面積あたり

$$
J_{\mathrm{R}}\left(V, E_{\mathrm{g}}\right)=\exp \left[V /\left(k_{\mathrm{B}} T_{\text {秦子 }}\right)\right] J_{\mathrm{R}}\left(E_{\mathrm{g}}\right)
$$

と表せられる。

一方，素子に入射する太陽光 AM1.5 のスペクトルの うち, 光学ギャップ以上の光の成分,

$$
J_{\mathrm{A}}\left(E_{\mathrm{g}}\right)=\int_{E_{\mathrm{g}}}^{\infty} d E^{\prime} B_{\mathrm{E}}\left(E^{\prime}\right) / E^{\prime}
$$

はすべて素子で吸収され，単位時間，単位面積あたり生 成されるキャリア数を与えるとする。（上式では，一光 子に相当するエネルギー $E=h \nu$ で割り, 光のエネルギ 一を光子数に変換している。ここで, $h$ はプランク定 数, レは光の振動数を表す。）避けることのできない輻 射再結合から逃れるキャリアによる電流は $J_{\mathrm{A}}\left(E_{\mathrm{g}}\right)-J_{\mathrm{R}}$ $\left(V, E_{\mathrm{g}}\right)$ となる。理論限界効率は, 電力を極大にする電 圧を用いて $\operatorname{Max}\left\{e V\left(J_{\mathrm{A}}\left(E_{\mathrm{g}}\right)-J_{\mathrm{R}}\left(V, E_{\mathrm{g}}\right)\right)\right\}_{V}$ を計算し入射 光の全エネルギーで割った ${ }^{3)}$

$$
Q_{\mathrm{SQ}}\left(E_{\mathrm{g}}\right)=\frac{\operatorname{Max}\left\{e V\left(J_{\mathrm{A}}\left(E_{\mathrm{g}}\right)-J_{\mathrm{R}}\left(V, E_{\mathrm{g}}\right)\right)\right\}_{V}}{I(0)}
$$

となる。Fig. 3 に SQ 理論限界効率を光学ギャップの関 数として示す。光学ギャップが大きいと, 吸収されない 光が損失となる。そのため光学ギャップは小さい方が光 吸収という点では変換効率を上げる因子となる。他方, 得られる電圧は光学ギャップより小さいため, 光学ギャ ップが小さいと電圧の観点では損失となる。この光学ギ ヤップの増減についての相反する性質のために，変換効 率の極大を与える光学ギャップが現れる。SQ 限界の最 大值は光学ギャップが 1.3〜 1.5 [eV] にありその值は約

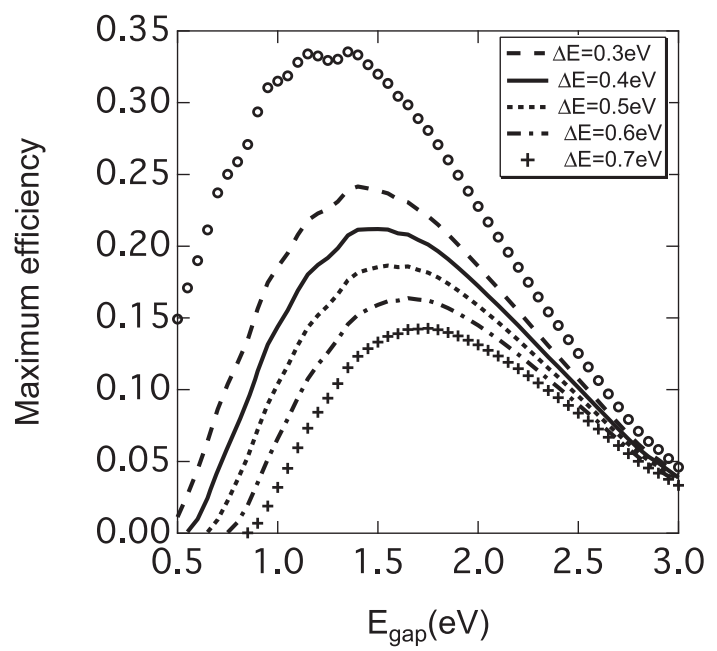

Fig. 3. Maximum efficiency as a function of the optical band-gap. The SQ limit is shown by circles. The other lines indicate the results including the dissociation energy of $\Delta E_{\mathrm{DA}}=0.3,0.4,0.5,0.6$ and $0.7[\mathrm{eV}]$ from top to bottom. The figure is reproduced from Ref. 7) with permission.
$33 \%$ である ${ }^{3)}$ 。

\section{2 有機薄膜太陽電池}

SQ 理論は, 一種類の半導体に対する変換効率の理論 限界を与える。しかし, 有機薄膜太陽電池は, ドナーと なる物質とアクセプターとなる物質を混合している。そ のために, SQ 理論では変換効率を求めることができな い。ドナーとアクセプターの界面で, ドナーカチオンと アクセプターアニオンに電荷分離する過程で, 余剩エネ ルギー $\Delta E_{\mathrm{DA}}$ が放出されることを考慮する必要があ $ろ^{8,9)}$ 。

光電変換の損失を与える因子として, ドナーカチオン とアクセプターアニオンの間の電荷再結合を考慮する。 SQ 理論と同様に，素子温度の空洞内での素子と輻射の 相互作用より, ドナーカチオンとアクセプターアニオン の間の電荷再結合の速度を求める。電荷分離の際のエネ ルギー損失 $\Delta E_{\mathrm{DA}}$ を考慮すると輻射再結合の速度は，単 位時間，単位面積あたり $J_{\mathrm{R}}\left(E_{\mathrm{g}}-\Delta E_{\mathrm{DA}}\right)$ となる。電圧の 影響を質量作用の法則により考慮すると，再結合による キャリアの流れは，単位時間，単位面積あたり

$$
J_{\mathrm{R}}\left(\mathrm{V}, E_{\mathrm{g}}-\Delta E_{\mathrm{DA}}\right)=\exp \left[V /\left(k_{\mathrm{B}} T_{\text {素子 }}\right)\right] J_{\mathrm{R}}\left(E_{\mathrm{g}}-\Delta E_{\mathrm{DA}}\right)
$$

となる。余剩エネルギーを考慮すると, 理論限界効率 は ${ }^{7)}$,

$$
Q\left(E_{\mathrm{g}}, \Delta E_{\mathrm{DA}}\right)=\frac{\operatorname{Max}\left\{e V\left(J_{\mathrm{A}}\left(E_{\mathrm{g}}\right)-J_{\mathrm{R}}\left(V, E_{\mathrm{g}}-\Delta E_{\mathrm{DA}}\right)\right)\right\}_{V}}{I(0)}
$$

となる。余㮃エネルギー $\Delta E_{\mathrm{DA}}$ を変えた場合の理論限界 効率の結果を Fig. 3 に示す。SQ 理論の結果と比較して, $\Delta E_{\mathrm{DA}}$ の増加に従い, 理論限界効率は低下する。これは, クーロン引力に抗して電荷分離するためにエネルギーが 使われたことに対応する。理論限界効率が極大を与える 光学ギャップは, $\Delta E_{\mathrm{DA}}$ の増加に従い, 高エネルギー側 ヘシフトしている ${ }^{7,8)}$ 。これは, $\Delta E_{\mathrm{DA}}$ の増加に従い, 電 荷再結合による電流の損失が増加するために, 高い電圧 により電力を稼ぐことが利得となるためである。光学ギ ヤップが高いことは，電圧の増加につながるために，理 論限界効率の極大を与える光学ギャップは高エネルギー 側へシフトしている。

多くの有機物質では光学ギャップは $1.8 \sim 2[\mathrm{eV}]$ 程 度である。 $\Delta E_{\mathrm{DA}}$ の最低值として $0.4[\mathrm{eV}]$ を取ると, 理論的な効率の最大值は光学ギャップが $1.8 〜 2[\mathrm{eV}]$ であると $18 \%$ 程度であり, 現状の最大 $11 \%$ 程度につい ては，まだ向上の余地がある。 $\Delta E_{\mathrm{DA}}=0.4[\mathrm{eV}]$ での光 電変換の最大值は約 $21 \%$ であり，これを与える光学ギ ヤップは $1.5[\mathrm{eV}]$ である7)。吸収波長の長波長化は, 効率向上に対して有効であることがわかる。 
ここで述べた理論における妥当な $\Delta E_{\mathrm{DA}}$ の值を推定す る方法として, 開放端電圧を光学ギャップの関数として 表現することが有効である。開放端電圧は，電流が流れ ない条件での電圧であることから

$$
J_{\mathrm{A}}\left(E_{\mathrm{g}}\right)-J_{\mathrm{R}}\left(\mathrm{V}, E_{\mathrm{g}}-\Delta E_{\mathrm{DA}}\right)=0
$$

より

$$
V_{\mathrm{OC}}=k_{\mathrm{B}} T_{\text {掌子 }} \log \left[\frac{J_{\mathrm{A}}\left(E_{\mathrm{g}}\right)}{J_{\mathrm{R}}\left(E_{\mathrm{g}}-\Delta E_{\mathrm{DA}}\right)}\right]
$$

と求められる。開放端電圧は, キャリアの光生成速度と 再結合の速度が釣り合っているときの電圧であると解釈 できる。 $V_{\mathrm{OC}}$ を $E_{\mathrm{g}}$ に対してプロットした結果を Fig. 4 に示す。 $V_{\mathrm{OC}}$ が $E_{\mathrm{g}}$ と等しいとすると点線となる。無機 半導体に対する $\mathrm{SQ}$ 理論では破線となる。さらに, $\Delta E_{\mathrm{DA}}=0.4[\mathrm{eV}]$ を考慮すると実線となる。文献 ${ }^{10)}$ の害 駼結果を黒丸で表しているが，実線と良い相関を示して いる。これらの実験值に対しては，最低でも $\Delta E_{\mathrm{DA}}=0.4$ [eV] であることを示唆している。

Fig. 4 では点線よりも破線の值は低くなっている。破 線は $V_{\mathrm{OC}}$ の低下のうち $\Delta E_{\mathrm{DA}}$ では捉えきれない成分を表 しているが，これは電荷再結合による損失の影響であ る。 $\Delta E_{\mathrm{DA}}$ はしばしばバンドオフセットと呼ばれる。ド ナーの LUMO（最低非占有準位）とアクセプターの LUMO との差で近似できると考えられる。Fig. 1 より， ドナーの HOMO とアクセプターLUMO の差は, $E_{\mathrm{g}}-\Delta E_{\mathrm{DA}}$ から求められる。

Fig. 5 では(10)式より得られる $e V_{\mathrm{OC}}$ を $E_{\mathrm{g}}-\Delta E_{\mathrm{DA}}$ に対 して示した。 $\Delta E_{\mathrm{DA}}$ の值にかかわらず

$$
e V_{\mathrm{OC}}=E_{\mathrm{g}}-\Delta E_{\mathrm{DA}}-0.2[\mathrm{eV}]
$$

と近似できることがわかる。

この関係式は，電荷再結合による開放端電圧の低下は $\Delta E_{\mathrm{DA}}$ の值にかかわらず，少なくとも $0.2[\mathrm{eV}]$ である と解釈できる ${ }^{8,11)}$ 。ただし，式(11) は理想化された関係 であり，ドナーとアクセプターのモルフォロジーによる 影響を受けるという報告がある ${ }^{12)}$

\section{3 色素増感型太陽電池}

色素増感型太陽電池は，有機薄膜太陽電池と多くの相 違があるが，原理的に最も異なるのは増感作用であ る ${ }^{13)}$ 。正負どちらの電荷輸送層でも, 吸収されない波長 の光を色素が吸収し，光励起された色素から，電荷輸送 層へキャリアが注入されることにより光起電力が生じ る。現在, 高効率の色素増感型太陽電池では, 負のキャ リア輸送層としては酸化チタン多孔質，正のキャリア輸 送としては電解液が用いられ，この組み合わせの電池の 発明者の名前により Grätzel cell と呼ばれている ${ }^{14)}$ 。

Fig. 6 に色素増感型太陽電池の電荷分離を模式的に示 す ${ }^{14,15)}$ 。光誘起電子移動により, 電子は励起色素から電

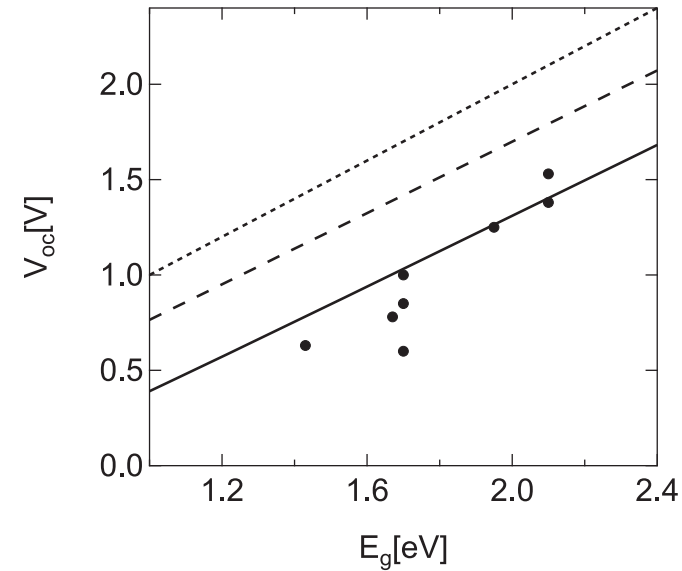

Fig. 4. Open circuit voltage $V_{\mathrm{OC}}$ as a function of the optical band-gap denotes by $E_{\mathrm{g}}$. The dotted line indicates $e V_{\mathrm{OC}}=E_{\mathrm{g}}$. The dashed line is obtained from SQ limit. The solid line is obtained for $\Delta E_{\mathrm{DA}}=0.4[\mathrm{eV}]$. The closed circles are taken from Ref. 10).

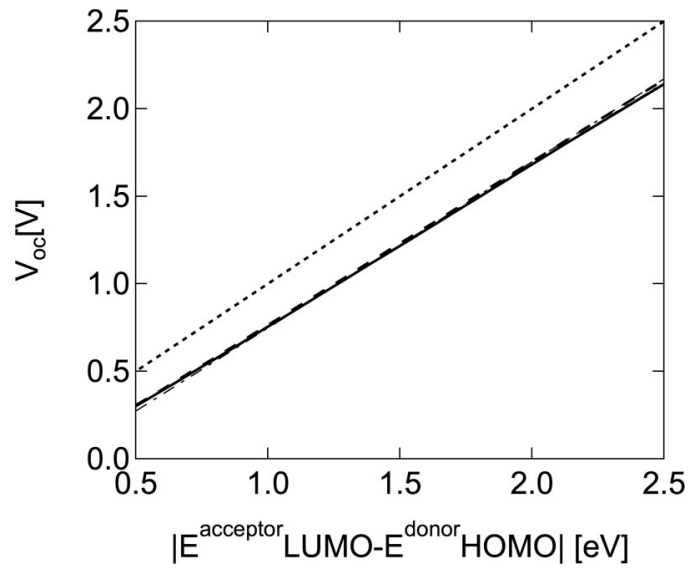

Fig. 5. Open circuit voltage $V_{\mathrm{OC}}$ as a function of $E_{\mathrm{g}}-\Delta E_{\mathrm{DA}}$. The dotted line indicates $e V_{\mathrm{OC}}=E_{\mathrm{g}}-\Delta E_{\mathrm{DA}}$. The dashed line is obtained from SQ limit. The solid line is obtained for $\Delta E_{\mathrm{DA}}=$ $0.4[\mathrm{eV}]$. The dash-dotted line denotes Eq. (11).

子輸送層へ注入され色素はカチオンとなる。電子の易動 度が十分に高い場合，酸化チタンから負のキャリアが流 入する電極と酸化チタンの擬フェルミ準位が一致する。 対極にある電極のフェルミ準位が電解液の還元電位と一 致している理想的な場合では, 電圧は, 酸化チタンの負 のキャリアの擬フェルミ準位と, 電解液の酸化還元電位 の差となる。色素への電子の流れは色素からの正孔の移 動と解釈できる。酸化状態にある色素カチオンは電解液 のイオンと反応し，光励起前の基底状態となる。

色素増感型太陽電池の余剩エネルギーには二種類あ る ${ }^{15)}$ 。一つは色素の励起準位と酸化チタンの電子の擬フ 


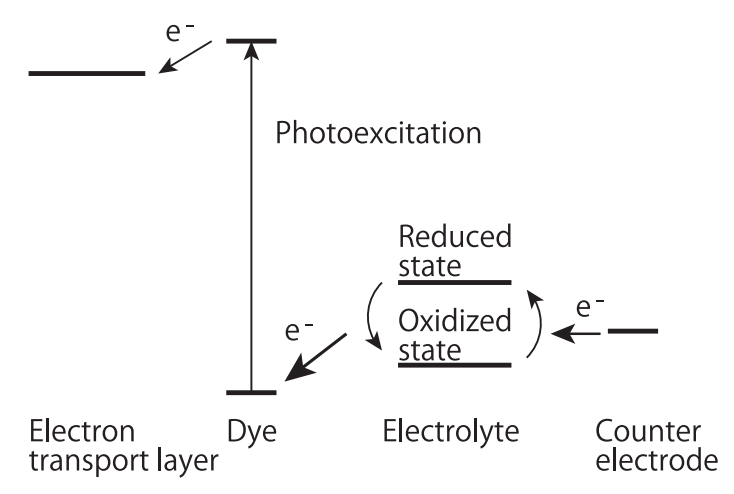

Fig. 6. Schematic energy diagram of charge dissociation processes in dye sensitized solar cells. Electron flow to the dye can be regarded as hole flow from the dye.

エルミエネルギーの差（電子注入余剩ポテンシャル）で ある。もう一つは, 電解液から色素への電子移動による 色素再生余剩ポテンシャルである。色素再生余剩ポテン シャルは, 色素カチオンおよび電解液の還元状態が中性 の色素および電解液の酸化状態へ変化するエネルギーの 差である。電子注入余剩ポテンシャルと色素再生余剩ポ テンシャルの和が正味の余剩エネルギーである。高い還 元電位を持つ電解質を用いることにより, 色素再生余剩 エネルギーを小さくすると効率の向上に繋がる。 Co（II/III）に基づいた電解質を用いることにより $12 \%$ 程度の変換効率が報告されている ${ }^{15)}$ 。

色素増感型太陽電池では, 再結合損失にも二種類あ る。一つは色素カチオンと電子輸送層に注入された電子 の再結合である。もう一つは, 電子輸送層にある電子に よる電解質の還元反応である。

最近の Grätzel 達の結果によると, 励起色素から酸化 チタンへの電子注入余剩ポテンシャルは約 $0.1[\mathrm{eV}]$, 色素カチオンと電解質の酸化還元電位から見積もられる 色素再生余剩ポテンシャルが $0.6[\mathrm{eV}]$ であるので余剩 エネルギーの合計は約 $0.7[\mathrm{eV}]$ となる ${ }^{16)}$ 。最近, 理想 的な電流電圧特性曲線を仮定することにより, 余剩エネ ルギーによる解放端電圧の低下を考慮した限界効率が理 論的に求められている ${ }^{17)}$ 。その結果によると余剩エネル ギーが 0.7 [eV] であると限界効率は約 $13 \%$ であった。 これに対して, $\mathrm{I}^{-} / \mathrm{I}^{3-}$ に基づいた電解質を用いた Grätzel cell の現在の効率の最大值は約 $11 \%$ であり，この理 論限界に近いことがわかる ${ }^{15,16)}$ 。このことは, EQE が $80 \%$ 以上と高いこととも整合している ${ }^{15)}$ 。一方, Fig. 3 を用いると, 色素の吸収は $E_{\mathrm{g}}=1.6[\mathrm{eV}]$, 余剩エネル ギーが $0.7[\mathrm{eV}]$, 電解質の還元が主要な損失因子であ る場合, 約 $13 \%$ となり妥当な值を与える。電解質の還 元反応は輻射再結合ではないのにもかかわらず, 妥当な
理論限界効率の值を与える理由については, 輻射電荷再 結合を仮定して得られた電流電圧特性が, 再結合の機構 の詳細によらず最適化された素子の性能に近いことを示 唆している。

\section{5. 有機薄膜太陽電池の理論限界の比較}

これまで, 有機系太陽電池の理論限界について, 主に 私たちの論文に従って紹介した7)。細かな相違がある が, 同様の研究が行われていることから,この章では, 二つの先行研究を紹介する。

文献 ${ }^{18)}$ では, 電荷分離により生成した電荷分離状態 (電荷移動錯体) は吸収係数を持っており, 輻射再結合 の大きさもこの吸収係数で決まるとした。吸収係数 $\alpha(E)$ は, $\mathrm{E}$ が $E_{\mathrm{g}}$ 以上では 1 であり, 光電変換効率は,

$$
Q\left(E_{\mathrm{g}}\right)=\frac{\operatorname{Max}\left\{e V\left(J_{\mathrm{A}}[\alpha(E)]-J_{\mathrm{R}}[V, \alpha(E)]\right)\right\}_{V}}{I(0)}
$$

と表される。ここで, $J_{\mathrm{A}}[\alpha(E)]$ と $J_{\mathrm{R}}[\alpha(E)]$ は, それぞ れ,

$$
\begin{aligned}
& J_{\mathrm{A}}[\alpha(E)]=\int_{0}^{\infty} d E^{\prime} \alpha(E) B_{\mathrm{E}}\left(E^{\prime}\right) / E^{\prime}, \\
& J_{\mathrm{R}}[V, \alpha(E)]=\exp \left[\frac{V}{k_{\mathrm{B}} T_{\text {素子 }}}\right] \int_{0}^{\infty} d E \alpha(E) J_{\mathrm{E}}\left(E, T_{\text {素子 }}\right)
\end{aligned}
$$

である。 $\mathrm{E}$ が $E_{\mathrm{g}}$ 以下で $\alpha(E)=0$ とすると $\mathrm{SQ}$ 理論と一 致する。 $\mathrm{E}$ が $E_{\mathrm{g}}-\Delta E_{\mathrm{DA}}$ 以上で 1 , それ以下では 0 とす ると, 変換効率の $E_{\mathrm{g}}$ での值は実際は, $E_{\mathrm{g}}-\Delta E_{\mathrm{DA}}$ での值 となるので, $\mathrm{SQ}$ 理論の横軸を右へ $\Delta E_{\mathrm{DA}}$ ずらすことに 対応する。 $\mathrm{E}$ が $E_{\mathrm{g}}$ 以下 $E_{\mathrm{g}}-\Delta E_{\mathrm{DA}}$ 以上で $\alpha(E)=0.001$ と すると変換効率の最大值は $\Delta E_{\mathrm{DA}}=0.3-0.5[\mathrm{eV}]$ を仮定 し 22〜27\% 程度と求められた。文献 ${ }^{199}$ の理論も, 同様 であるが, $J_{\mathrm{R}}[V, \alpha(E)]$ を

$$
\left(\exp \left[V /\left(k_{\mathrm{B}} T_{\text {素子 }}\right)\right]-1\right) \int_{0}^{\infty} d E \alpha(E) J_{\mathrm{E}}\left(E, T_{\text {素子 }}\right)
$$

としている。輻射再結合の流れをダイオード飽和電流を 用いて解釈し直していることに対応する。 $V=0$ でゼロ となり, 短絡電流は吸収された光子の流れ, $J_{\mathrm{A}}[\alpha(E)]$ と等しくなる。光電変換効率については, 文献 ${ }^{18)}$ とほぼ 同じ結果を与える。

これらの吸収係数を導入する理論では, 吸収と輻射 は, 光の各波長で鈞り合っているという Kirchhoff の法 則を用いて，吸収と輻射による損失を直接関係付けてい る。Kirchhoff の法則は, 蛍光を発しない物質について, 証明されている ${ }^{20)}$ 。有機物質は蛍光体であり, 吸収と発 光の波長依存性は異なる。光の各波長で吸収と輻射が釣 り合っておらず Kirchhoff の法則は成立しない211。これ は, 有機物質では, 無輻射緩和が避けられないことに起 因しているが, Fig. 1 で表される電荷分離でも非発光の 
エネルギーの損失が起こっている。前章では，この非発 光過程を考慮するため, Kirchhoff の法則を用いていな い。詳細については文献》の Appendix を参照して頂き たい。

\section{6. 有機薄膜太陽電池の電荷分離素過程}

4 章での限界効率の計算では, Fig. 1 で表されている 不可逆な電荷分離は考慮されているが，無輻射再結合は 考慮されていない。電荷分離した電荷対が一旦分離し同 じ対間で再結合するとき，対再結合と呼ばれる。対再結 合には，拡散したキャリアが，元の対の相手のキャリア と相界面で出会い再結合をする場合も含んでいる。正の キャリアは対再結合を逃れても, 別の対から生成した負 のキャリアと相界面で再結合することがある。対再結合 を逃れたキャリア間の再結合はバルク再結合（非対再結 合）と呼ばれる。対再結合，バルク再結合にかかわら ず，電荷再結合反応は電荷分離反応の逆電子移動反応で ある。電荷分離も電荷再結合についても, 電子移動反応 であり，有機物質中での電子移動はマーカス式で表され る ${ }^{22)}$ 。この章では, 有機物質中でのマーカス式による電 子移動の例として電荷分離反応を取り上げる。

以下，励起ドナー分子からアクセプター分子への電荷 分離が電子移動反応である場合を取り上げる。有機分子 の励起状態は, 電荷分離と競合する熱失活を起こすが, そのエネルギーは振電相互作用を介して，分子の熱振動 となる。振電相互作用の大きさは振動子強度で表され る。電子移動速度に対する振電相互作用の寄与は, Huang Rhys 因子と呼ばれる重みで特徴付けられる。 Huang Rhys 因子は無次元量であるが，代表的な振動の エネルギーをかけると電子移動の再配向エネルギーを与 え, 約 $\lambda_{\mathrm{HR}}=0.1 \sim 0.3 \mathrm{eV}$ である。

有機物質の誘電率は低いが，キャリアの電荷との誘電 的な相互作用による再配向エネルギーも無視できない。 有機太陽電池素子を比誘電率 $\varepsilon=3.5$, 光学的な誘電率 $\varepsilon_{\mathrm{op}}=1.8 \sim 2$ の一様な誘電体とすると, マーカスの再配 向エネルギー,

$$
\lambda_{\mathrm{d}}=\frac{1}{2} \frac{e^{2}}{4 \pi \epsilon_{0}}\left(\frac{1}{\varepsilon_{\mathrm{op}}}-\frac{1}{\varepsilon}\right)\left(\frac{1}{R_{\mathrm{D}}}+\frac{1}{R_{\mathrm{A}}}-\frac{2}{R}\right)
$$

は，ドナーとアクセプターの分子半径を $R_{\mathrm{D}}=R_{\mathrm{A}}=5 \AA$, 電荷分離したカチオンとアニオン間の距離を $R=10 \AA$, とすると $\lambda_{\mathrm{d}}=0.4[\mathrm{eV}]$ となる。誘電的な相互作用によ る再配向エネルギーは，振電相互作用による再配向エネ ルギーに匹敵することがわかる222。

電荷分離の速度定数 $k_{\mathrm{CS}}$ のエネルギーギャップ依存性 はマーカス理論を用いて,

$$
\frac{2 \pi J^{2}}{\hbar} \frac{1}{\sqrt{4 \pi k_{\mathrm{B}} T\left(\lambda_{\mathrm{d}}+\lambda_{\mathrm{HR}}\right)}} \exp \left(-\frac{\left(\Delta G_{\mathrm{CS}}+\lambda_{\mathrm{d}}+\lambda_{\mathrm{HR}}\right)^{2}}{4\left(\lambda_{\mathrm{d}}+\lambda_{\mathrm{HR}}\right) k_{\mathrm{B}} T}\right)
$$

と表すことができる ${ }^{23)}$ 。ここで， はプランク定数，J は移動積分, $\Delta G_{\mathrm{CS}}$ は電荷分離に伴う自由エネルギー変 化である。 $\Delta E_{\mathrm{DA}}$ はドナーとアクセプター間の距離が無 限に離れたときの $\Delta G_{\mathrm{CS}}$ の符号を変えた

$$
\Delta E_{\mathrm{DA}}=-\Delta G_{\mathrm{CS}}-\frac{e^{2}}{4 \pi \varepsilon \epsilon_{0} R}
$$

で表されると考えられる。電荷分離の速度定数 $k_{\mathrm{CS}}$ の極 大を与える $\Delta E_{\mathrm{DA}}$ は, $\Delta G_{\mathrm{CS}}+\lambda_{\mathrm{d}}+\lambda_{\mathrm{HR}}=0$ から求めること ができ

$$
\lambda_{\mathrm{d}}+\lambda_{\mathrm{HR}}-\frac{e^{2}}{4 \pi \varepsilon \epsilon_{0} R}
$$

となる。電子移動速度が極大でなくても, 界面でのエキ シトンの寿命より速ければ電荷分離の効率は高いが，式 (18) は電荷分離効率が高い $\Delta E_{\mathrm{DA}}$ の目安を与えると考え られる。上記の $\varepsilon, \varepsilon_{\mathrm{op}}, R_{\mathrm{D}}, R_{\mathrm{A}}$ そして $R$ を用いると, この值は $0.2[\mathrm{eV}]$ 程度と見積もられる。この值は $\lambda_{\mathrm{HR}}$ と同程度の小さな值であるため, マーカス理論に由来す る連続体理論や，分子の形，距離についての誤差が大き いと考えられる。

電荷分離状態は正負の電荷が界面を離れ，それぞれド ナー相とアクセプター相をホッピングで電荷移動しても 前述の Bjerrum 長（164 ̊程度）以上離れなければ，熱 エネルギーがクーロン相互作用を上回らない。電荷分離 の速度定数だけではなく，ドナー相とアクセプター相の 中での電荷移動も考慮すると, 電荷分離の確率はドナー 相とアクセプター相の形や界面に依存する ${ }^{24)}$ 。素過程に 基づいて電荷分離の確率を求めるためには, 電荷分離し た電荷対が少なくとも Bjerrum 長以上離れるまでの電荷 移動と再結合を考慮する必要がある。

光強度が高く, 生成される電荷対間の平均距離が Bjerrum 長 (164 ̊ 程度) より短い場合には, 電流の向 きに垂直である界面に対して，界面での電荷蓄積を特徵 付ける長さを定義することができる。電荷蓄積領域の厚 みは, 電流密度 $I$ と電荷の拡散定数 $D$ を用いて $\left[e D /\left(2 \pi I r_{\mathrm{c}}\right)\right]^{1 / 3}$ と表される ${ }^{25,26)}$ 。電流密度に比較して電 荷の易動度が小さく，また Bjerrum 長が長いとこの領域 は狭く, 界面近傍に多くの電荷が蓄積される。I〜 1 $\left[\mathrm{mA} / \mathrm{cm}^{2}\right]$ ，易動度 $10^{-4}\left[\mathrm{~cm}^{2} /(\mathrm{Vs})\right]$ ，であると約 30 $\mathrm{nm}$ となる。易動度の低い有機薄膜太陽電池でのバルク 再結合では，この界面における電荷蓄積の効果も重要で あろう。

素過程を積み上げて電荷分離の確率を求めることは理 想ではあるが現状では克服すべき課題が多い。SQ 理論 に基づいた有機薄膜太陽電池の光電変換効率の計算は, 
可能な限り輻射の統計理論を援用することによりこの困 難を回避した試算である。

\section{7. ま め}

再結合が輻射を伴う場合には，再結合による損失は， 入射光と輻射が定常状態では釣り合うことと，黒体輻射 のスペクトルから決めることができた。素子の黒体輻射 は避けることができないことから限界効率と考えられて いる。あえて標語的にまとめると「良く光る素子は, 効 率が良い」ということになる ${ }^{27)}$ 。GaAs に代表される直 接遷移型の無機半導体については, SQ 理論から得られ る限界効率の值は, 理想值として考えられる。これに対 して, 有機分子の振電相互作用は一般的に強いため, 無 輻射である熱的失活が起こりやすい。本総説では電荷分 離について, 無輻射な失活を考虑した理論を紹介し た7)。無輻射再結合による損失を理論的に求めるために は, 電荷分離のみならず電荷再結合についてもマーカス 式に立脚した素過程を考慮しなければならないと考えて いる。

2013 年以降爆発的に研究が進展している, 有機無機 ハイブリッドペロブスカイト型太陽電池については比誘 電率が 20 以上あり, 励起子の電荷分離に界面を必要と する Excitonic 太陽電池ではないようだ。しかし，電荷 分離機構に不明な点が多く, 本総説では触れることがで きなかった。

\section{謝 辞}

共同研究者の古部昭広氏と吉田郵司氏からの有益なコ メントに感謝いたします。

\section{文献}

1) http://www.nrel.gov/ncpv/

2) P.K. Nayak, G. Garcia-Belmonte, A. Kahn, J. Bisquert and D. Cahen : Energy Environ. Sci. 5, 6022 (2012).

3) W. Shockley and H.J. Queisser : J. Appl. Phys. 32, 510
(1961).

4) http://rredc.nrel.gov/solar/spectra/

5) G. Dennler, M.C. Scharber and C.J. Brabec : Adv. Mater. 21, 1323 (2009).

6) C.W. Tang : Appl. Phys. Lett. 48, 183 (1986).

7) K. Seki, A. Furube and Y. Yoshida : Appl. Phys. Lett. 103, 253904 (2013).

8) A.W. Hains, Z. Liang, M.A. Woodhouse and B.A. Gregg : Chem. Rev. 110, 6689 (2010).

9) B.A. Gregg : J. Phys. Chem. B 107, 4688 (2003).

10) D. Veldman, S.C.J. Meskers and R.A.J. Janssen : Adv. Funct. Mater. 19, 1939 (2009).

11) J.D. Servaites, M.A. Ratner and T.J. Marks : Energy Environ. Sci. 4, 4410 (2011).

12) B.P. Rand, D.P. Burk and S.R. Forrest : Phys. Rev. B 75, 115327 (2007).

13) H. Tsubomura, M. Matsumura, Y. Nomura and $T$. Amamiya : Nature 261, 402 (1976).

14) B. O’Regan and M. Grätzel : Nature 353, 737 (1991).

15) A. Yella, H.W. Lee, H.N. Tsao, C. Yi, A.K. Chandiran, M.K. Nazeeruddin, E.W. Diau, C.Y. Yeh, S.M. Zakeeruddin and M. Grätzel : Science 334, 629 (2011).

16) B.E. Hardin, H.J. Snaith and M.D. McGehee : Nat. Photonics 6, 162 (2012).

17) H.J. Snaith : Adv. Funct. Mater. 20, 13 (2010).

18) N.C. Giebink, G.P. Wiederrecht, M.R. Wasielewski and S.R. Forrest: Phys. Rev. B 83, 195326 (2011).

19) T. Kirchartz, K. Taretto and U. Rau : J. Phys. Chem. C 113, 17958 (2009).

20) L.D. Landau and E.M. Lifshitz: "Statistical Physics 3rd Ed. Part 1” (Pergamon, Oxford, 1993) p. 188.

21) B. Valeur and M.N. Berberan-Santos : J. Chem. Educ. 88, 731 (2011).

22) K. Seki and M. Tachiya: Phys. Rev. B 65, 014305 (2001).

23) R.A. Marcus : Rev. Mod. Phys. 65, 599 (1993).

24) M. Wojcik, P. Michalak and M. Tachiya : Appl. Phys. Lett. 96, 162102 (2010).

25) G.T. Wright : Solid-State Electron. 2, 165 (1961).

26) K. Seki : J. Appl. Phys. 116, 063716 (2014).

27) O.D. Miller, E. Yablonovitch and S.R. Kurtz : IEEE J. Photovoltaics 2, 303 (2012). 